\title{
METADOXINE REGULATION OF ELIMINATION OF ETHANOL AND ITS METABOLITES FROM THE RAT'S BODY
}

\author{
M.Ya.Golovenko, O.V.Karpova, I.Yu.Borisyuk
}

\author{
A.V.Bogatsky Physico-Chemical Institute of NAS of Ukraine, Odessa
}

Key words: metadoxine; ethanol; acetaldehyde; acetate; radiological analysis

\begin{abstract}
Development of pathogenetic therapy of acute ethanol poisoning is of undoubted interest since such intoxication is often accompanied by a severe course and high lethality. Taking into account the peculiarities of the ethanol pathological action the treatment of such patients involves the use of drugs with the complex neuro- and hepatoprotective effects. Thereby, the studies for searching new pharmaceutical agents with a wide range of the pharmacological activity and economic availability continue. For a long time the object of researchers' attention is the chemical compound - pyridoxineL-2-pyrrolidone-5-carboxylate (metadoxine). Till this moment a large number of the experimental data showing a diverse pharmacological profile of the drug action (antioxidant, antisteatotic, anti-inflammatory, antifibrotic, neurotropic) has been accumulated. Paying attention to the facts mentioned above our attention was focused on the detoxification action of metadoxine. Therefore, the aim of this work was to study the effect of metadoxine on the rate of excretion of ethanol and its metabolites in white rats in a preventive single introduction of the drug. The parameters of excretion of acetaldehyde, acetate and the unchanged ethanol with urine and feces have been chosen as a criterion for assessing the effectiveness of the process. Excretion of ethanol by lungs and sweat glands has not been studied because of a negligible contribution of these pathways in the process of ethanol elimination. It has been determined that intraperitoneal introduction of metadoxine in the dose of $200 \mathrm{mg} / \mathrm{kg} 30 \mathrm{~min}$ prior ethanol introduction (orally in the dose of $1 \mathrm{~g} / \mathrm{kg}$ ) accelerates the rate of elimination of ethanol and its metabolites (acetaldehyde and acetate) in rats.
\end{abstract}

$\mathrm{D}^{2}$ evelopment of pathogenetic therapy of acute ethanol poisoning is of undoubted interest since such intoxication is often severe and highly lethal. Treatment of acute poisoning with ethyl alcohol traditionally includes a set of measures maintaining the vital functions and constant internal environment, as well as measures aimed to accelerate ethanol elimination [5, 14]. Currently, there is large number of drugs used in medical practice for the treatment of the effects of the ethanol action on the human body. Taking into account the peculiarities of ethanol pathological action the treatment of such patients involves the use of drugs with the complex neuro- and hepatoprotective effects.

Thereby, the studies for searching new pharmaceutical agents with a wide range of the pharmacological activity and economic availability continue. For a long time the object of researchers' attention is the chemical compound pyridoxine-L-2-pyrrolidone-5-carb- oxylate (metadoxine), which is an equimolar combination of pyrrolidone carboxylate (A) and pyridoxine (B) as an ionic salt (Fig.).

L-2-pyrrolidone-5-carboxylate (pyroglutamate, 5-oxoproline) is included to the substance due to the possibility of this cyclic lactam of glutamic acid (an intermediate of the gamma - glutamine cycle) to be involved in the glutathione metabolism [15].

The cationic part of metadoxine is presented as pyridoxine possessing the vitamin activity (one of vitamin $\mathrm{B}_{6}$ three forms). The compound plays an important role in metabolism of the substances involved in the synthesis of neurotransmitters. The phosphorylated form participates in the processes of decarboxylation, transamination and deamination of amino acids, improves the use of unsaturated fatty acids, reduces the level of cholesterol and lipids in the blood $[7,10]$.

As the active pharmaceutical ingredient metadoxine has been developed by "Laboratory Balda-

\footnotetext{
M.Ya.Golovenko - academician of NAMS of Ukraine, Doctor of Biology, head of the Physico-Chemical Pharmacology Department of A.V.Bogatsky Physico-Chemical Institute of NAS of Ukraine (Odessa)
}

chi S.P.A." (Italy). The generic of this drug is manufactured in Ukraine by ALC "INTERCHEM" in the form of tablets ("Alkodez ${ }^{\circledR} \mathrm{IC}$ " and "Liveriya ${ }^{\circledR} \mathrm{IC}^{\prime}$ ).

Till this moment a large number of the experimental data showing a diverse pharmacological profile of the drug action (antioxidant, antisteatotic, anti-inflammatory, antifibrotic, neurotropic) has been accumulated.

Paying attention to the facts mentioned above our attention was focused on the detoxification action of metadoxine.

Therefore, the aim of this work was to study the effect of metadoxine on the rate of excretion of ethanol and its metabolites in white rats in a preventive single introduction of the drug. The parameters of excretion of acetaldehyde, acetate and unchanged ethanol with urine and feces were chosen as a criterion for assessing the effectiveness of the process. Excretion of ethanol by lungs and sweat glands has been not studied because of a negligible contribution of these pathways in the process of ethanol elimination [11]. 


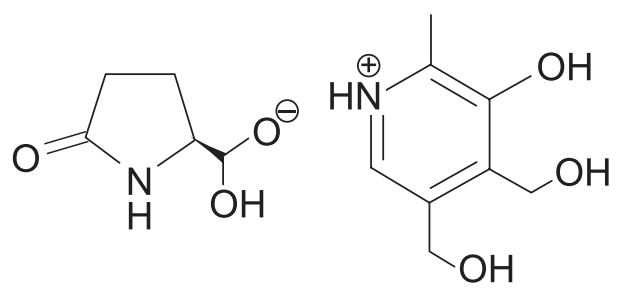

Fig. The formula of pyridoxine-L-2-pyrrolidone-5-carboxylate (metadoxine)

\section{Materials and Methods}

Experiments were conducted on white male Wistar rats weighing 200-270 g. Care of the animals and the experimental studies were carried out in accordance with the regulatory requirements $[1,2]$. The animals were divided into 2 groups: group 1 - control, and group 2 - test. The experimental animals received metadoxine (i.p., $200 \mathrm{mg} / \mathrm{kg}$ ) $30 \mathrm{~min}$ before the main introduction. Ethanol was administered orally in the dose of $\mathrm{S} \mathrm{LD}_{50}(3.5 \mathrm{~g} / \mathrm{kg})$ by two groups of animals.

Collection of excretes was in 3; 6; 12; 24 and $30 \mathrm{~h}$. When collecting the urine the funnel was washed 4 times with $10 \mathrm{ml}$ of $\mathrm{H}_{2} \mathrm{O}$, the total volume of the sample obtained (with overflows) was recorded. To determine the total radioactive material $1.0-2.0 \mathrm{ml}$ of the sample were collected in scintillation vials. Quantification of the content of acetic acid was performed in scintillation vials. Of the total volume $10 \mathrm{ml}$ of the sample were taken, and $1 \mathrm{ml}$ of $10 \% \mathrm{Na}_{2} \mathrm{CO}_{3}$ was added, then it was evaporated to obtain a semi-dry residue. To determine acetaldehyde $10.0 \mathrm{ml}$ were taken into a vial from the residue of the total sample, and hydrogen peroxide was added to oxidize acetaldehyde containing in the sample to acetic acid. Oxidation was carried out for $20 \mathrm{~min}$, then $1 \mathrm{ml}$ of $10 \% \mathrm{Na}_{2} \mathrm{CO}_{3}$ was added to adjust the alkaline $\mathrm{pH}(\geq 8.2)$, and it was evaporated to obtain a semi-dry residue. Feces were collected, placed in an oven, and then the samples were weighed. After grinding $50 \mathrm{mg}$ of the samples were collected in each vial, $1 \mathrm{~cm}^{3}$ of formic acid was added, and hydrolyzed on a water bath. In all cases, $1 \mathrm{~cm}^{3}$ of Triton X-100 and $10 \mathrm{~cm}^{3}$ of a scintillator of the Canberra Packard firm were added to the samples. The quantity of the radioactive material in the samples was determined by a Canberra PACKARD TRI CARB 2700 liquid scintillation photometer.

Processing of the results obtained was carried out in accordance with the algorithms [4]. In comparative analysis of the results of our studies Student's t-test was used [3]. The confidence interval in all the experiments was calculated at the significance level of $\mathrm{P} \leq 0.05$, providing the reliability of the results with the probability of $95 \%$.

All mathematical calculations were performed using the Excel XP software package of the personal computers (Pentium 4).

\section{Results and Discussion}

The limiting stage of the ethanol action is the absorption process, which is carried out mainly in the proximal part of the gastrointestinal (GI) tract, in the stomach $(70 \%)$ and in the duodenum (25\%), while $5 \%$ of ethanol is absorbed in the distal intestine [13].

The first stage of the metabolism of alcohol occurs in the gastric mucosa with participation of the gastric fraction of alcohol dehydrogenase. According to some sources up to $10 \%$ of the ethanol administered is metabolized in the stomach [6]. However, it should be noted that at present time the issue of the stomach as an organ where the first phase of the metabolism of ethanol occurs is discussed. It is suggested that the first phase of the alcohol metabolism takes place in the li- ver [9], but it depends on the rate of absorption in the stomach and small intestine.

It has been found that systemic ethanol oxidation occurs in the liver by three parallel metabolic pathways: 1) by alcohol dehydrogenase providing metabolism of the major amount (90\%) of alcohol in the liver, 2) by microsomal monooxygenase containing cytochrome P-450 2E1 (8-10\% of ethanol oxidation), 3) by peroxisome catalase (oxidation to $2 \%$ of ethanol) [12]. Oxidation of ethanol by alcohol dehydrogenase requires participation of $\mathrm{NAD}^{+}$, due to which the proton transfers from the ethanol molecule to a molecule of $\mathrm{NAD}^{+}$with its reduction to NADH and formation of acetaldehyde. Further, in the mitochondria, acetaldehyde in a NAD-dependent reaction is converted into acetic acid via acetaldehyde dehydrogenase; in its turn, with participation of acetyl coenzyme A synthetase, acetic acid is involved in formation of acetyl-CoA involving in the Krebs cycle or the fatty acids cycle. NADH formed during this reaction oxidizes again. Thus, the alcohol degradation rate by alcohol dehydrogenase and aldehyde dehydrogenase depends on the intensity of the reoxidation of NADH to $\mathrm{NAD}^{+}$. The metabolism of one molecule of alcohol requires two molecules of $\mathrm{NAD}^{+}$. This significantly alters the redox potential of hepatocytes towards the reduction reactions. Degradation of alcohol can be inhibited if NADH is not constantly re-oxidized. The increase in the NADH concentration decelerates the reactions of the Krebs cycle. Under these conditions the excess of acetyl-CoA is consumed in the synthesis of ketone bodies entering the blood. This mechanism of ethanol metabolism is used to create medicines affecting the pathological units appearing during use (especially abuse) of alcohol.

At the first stage the kinetics of the total elimination of ethanol and its metabolites with the nor- 
mal and preliminary introduction of metadoxine in white rats was studied.

It has been found that metadoxine increases the total amount of radioactive products (Tab. 1) by $30 \mathrm{~h}$ after introduction exceeding the similar value after introduction of ethanol in 1.4 times (from $32.6 \pm 5.6$ to $46.1 \pm 5.5 \%$ of the injected dose of ethanol). However, increase in the amount of the excreted total metabolites (on the background of metadoxine introduction is observed only in $7.5 \mathrm{~h}$ after introduction of ethanol, while by the third hour after introduction their quantity is eliminated higher in the group of intact animals (19.6 $\pm 2.3 \%$ of the injected dose). This difference is explained by the fact that the effect of metadoxine is due to modulation of biochemical processes. In this regard, the important question is not only about the elimination rate of the total amount of metabolites of ethanol, but about their quantitative composition as well.

There is an intensive metabolism of ethanol (increase in the acetate content in the urine is observed with time) as seen from the data presented (Tab. 2). Already from $\sim 7$ hour after introduction the amount of the excreted unchanged ethanol does not exceed $1 \%$ of the injected dose, while the major part of radioactive products is its metabolites - acetaldehyde (15-24\%) and acetate (59-84\%). Acetate formation in this case is
Table 1

Excretion of ethanol and its metabolites (\% of the injected dose) from the organism of the experimental animals after a single introduction of ethanol (control) and on the background of the preliminary introduction of metadoxine (test)

\begin{tabular}{|c|c|c|}
\hline Time, $\mathrm{h}$ & $\begin{array}{c}\text { Introduction } \\
\text { of ethanol (control) }\end{array}$ & $\begin{array}{c}\text { Preliminary introduction } \\
\text { of metadoxine }\end{array}$ \\
\hline 3 & $19.6 \pm 2.3$ & $13.9 \pm 1.3$ \\
\hline 7.5 & $25.7 \pm 3.6$ & $29.6 \pm 3.2$ \\
\hline 12 & $29.3 \pm 2.4$ & $37.5 \pm 2.4$ \\
\hline 24 & $32.2 \pm 2.5$ & $43.6 \pm 1.7$ \\
\hline 30 & $32.6 \pm 5.6$ & $46.1 \pm 5.5$ \\
\hline
\end{tabular}

Note: $p \leq 0.05$.

the leading pathogenetic factor since it leads to metabolic acidosis and disturbance of the body homeostasis, while acetaldehyde formed because of its volatility is eliminated from the body not only by renal, but also by respiratory routes, reducing its toxicity.

There is a significant redistribution of the profile of the excreted ethanol and its metabolites against the background of the preliminary introduction of metadoxine. Thus, the relative amount of the excreted unchanged ethanol (from $15.9 \pm 0.6$ to $77.8 \pm 0.6 \%$ in the first $3 \mathrm{~h}$ after introduction) significantly increases. At the same time the amount of the excreted unchanged acetaldehyde also increases (by $12 \mathrm{~h}$ after introduction increases from $18.2 \pm 2.8$ to $42.3 \pm 2.7 \%$ ). Simultaneously, the relative amount of the excreted acetate decreases in $\sim 2.3$ times (being $28.1 \pm 0.8 \%$ in $30 \mathrm{~h}$ after introduction). This difference in the ratio of the excreted unchanged ethanol and its metabolites is the result of increasing of its metabolism.

For integral characteristic of the excretion processes based on the amount of the common excreted metabolites (Tab. 1) and their relative composition (Tab. 2) the indicators of the maximum amount of the excreted compounds (Tab. 3) at the theoretically infinite exposure time $\left(Q_{\max }\right)$, as well as the kinetic characteristics of these processes (excretion constant, $\mathrm{k}_{\mathrm{ex}}, \mathrm{h}^{-1}$ ) were calculated. Noteworthy is the fact that the values of the unchanged ethanol $\mathrm{Q}_{\max }$ (increasing from $6.3 \pm 0.6 \%$ to $38.5 \pm 4.8 \%$ ) and its final metabolite - acetate (decreasing from $19.9 \pm 3.1 \%$ to $8.5 \pm$ $\pm 0.7 \%$ ) change most of all, while amount of the excreted acetaldehyde undergoes no statistically significant changes (Tab. 3 ).

The mechanism of the metadoxine stimulating effect on the

Table 2

\section{The relative composition (\% of the total radioactivity eliminated) of ethanol metabolites following the single introduction of ethanol (control) and on the background of the preliminary introduction of metadoxine (test)}

\begin{tabular}{|c|c|c|c|c|c|c|}
\hline \multirow{2}{*}{$\begin{array}{c}\text { Time, } \\
h\end{array}$} & \multicolumn{2}{|c|}{ Introduction of ethanol (control) } & \multicolumn{2}{c|}{ Preliminary introduction of metadoxine } \\
\cline { 2 - 7 } & Ethanol & Acetaldehyde & Acetate & Ethanol & Acetaldehyde & Acetate \\
\hline 3 & $15.9 \pm 0.6$ & $24.4 \pm 1.4$ & $59.6 \pm 0.8$ & $77.8 \pm 0.6$ & $9.9 \pm 0.7$ & $12.5 \pm 0.8$ \\
\hline 7.5 & $0.54 \pm 0.04$ & $23.9 \pm 2.7$ & $75.5 \pm 2.8$ & $58.8 \pm 0.6$ & $28.4 \pm 0.8$ & $12.79 \pm 0.4$ \\
\hline 12 & $0.73 \pm 0.01$ & $18.2 \pm 2.8$ & $81.1 \pm 2.9$ & $37.1 \pm 4.3$ & $42.3 \pm 2.7$ & $20.7 \pm 2.1$ \\
\hline 24 & $0.32 \pm 0.17$ & $16.9 \pm 2.8$ & $82.7 \pm 3.0$ & $32.6 \pm 5.3$ & $40.4 \pm 4.3$ & $27.1 \pm 0.9$ \\
\hline 30 & $0.28 \pm 0.09$ & $15.5 \pm 1.7$ & $84.2 \pm 1.8$ & $32.6 \pm 5.8$ & $38.8 \pm 5.1$ & $28.1 \pm 0.8$ \\
\hline
\end{tabular}

Note: $p \leq 0.05$. 
Table 3 and hence the necessary dehyd-

The change of the maximum amount $\left(Q_{\max } \%\right.$ of the injected dose) and the excretion constants $\left(k_{e x}, h^{-1}\right)$ of the excreted ethanol and its metabolites after its single introduction (control) and on the background of the preliminary introduction of metadoxine (test)

\begin{tabular}{|l|c|c|}
\hline \multicolumn{3}{|c|}{ Introduction of ethanol (control) } \\
\hline & $\mathrm{Q}_{\max }$ & $\mathrm{k}_{\mathrm{ex}} \mathrm{h}^{-1}$ \\
\hline The total metabolites of ethanol & $29.8 \pm 4.7$ & $0.32 \pm 0.05$ \\
\hline Ethanol & $6.3 \pm 0.6$ & $0.42 \pm 0.38$ \\
\hline Acetaldehyde & $0.6 \pm 0.2$ & $0.37 \pm 0.14$ \\
\hline Acetate & $19.9 \pm 3.1$ & $0.27 \pm 0.04$ \\
\hline Introduction of ethanol after preliminary introduction of metadoxine (test) \\
\hline The total metabolites of ethanol & $47.4 \pm 4.9$ & $0.12 \pm 0.01$ \\
\hline Ethanol & $38.5 \pm 4.8$ & $0.13 \pm 0.02$ \\
\hline Acetaldehyde & $0.7 \pm 0.2$ & $0.09 \pm 0.02$ \\
\hline Acetate & $8.5 \pm 0.7$ & $0.076 \pm 0.006$ \\
\hline
\end{tabular}

Note: $p \leq 0.05$.

process of ethanol elimination has not been completely elucidated. The elimination rate of ethanol may increase as a result of activation of the primary metabolism of ethanol in the gastrointestinal tract, intensification of the hepatic blood flow, induction of the synthesis of alcohol oxidation enzymes in the liver or re-oxidation of NADH. The latest mechanism deserves the greatest attention. The intensity of the reoxidation NAD(P)H process is a limited element determining the rate of any dehydrogenase reaction, including metabolism of ethanol to acetaldehyde followed by formation of acetic acid. The functioning of these enzymes is limited by the presence and availability of the oxidized form of $\mathrm{NAD}^{+}$. An excess of protons in alcohol intoxication does not allow the NAD/NADH system to transport all of them in the chain of biological oxidation enzymes. In this situation, the catalytic activity of alcohol dehydrogenase and aldehyde dehydrogenase is high, but their actions are blocked. To accelerate the oxidation of ethanol and acetaldehyde the efficiency of NAD/NADH turnover must be increased. There is information [8] that metadoxine under conditions of alcohol intoxication can maintain the normal ratio of $\mathrm{NAD}^{+} / \mathrm{NADH}$ in cells, rogenase activity, thus providing a high rate of ethanol biotransformation.

On the other side, such difference is explained by acceleration of acetate disposal (its inclusion in the energy and plastic metabolism), whereby its quantity excreted with the urine significantly decreases. By feedback acetate oxidation leads to the increased amounts of NADH and NADPH (and increase in the ratio of $\mathrm{NADPH} / \mathrm{NADP}^{+}$), which in turn, reduces the activity of alcohol dehydrogenase, and increases the amount of unmetabolized ethanol. It is observed in the experiment.

These mechanisms prevent development of ketosis and metabolic acidosis in acute alcohol intoxication. The increased rate of ethanol elimination is accompanied with the accelerated reduction of intoxication and the toxic effect.

\section{CONCLUSIONS}

Based on the data obtained it can be concluded that the prior introduction of metadoxine accelerates the metabolic degradation of ethanol and its metabolites, which appearance and accumulation are responsible for development of the toxic effect of alcohol. These results allow considering the further study of the possible use of the drug to be promising for prevention of acute alcohol intoxication.

\section{REFERENCES}

1. Доклінічні дослідження лікарських засобів: Метод. рекоменд. / За ред. А.В.Стефанова. - К.: Вид. дім «Авіценна», 2002. - 527 с.

2. Кожем'якін Ю.М., Хромов О.С., Філоненко М.А., Сайфетдінова М.А. Науково-практичні рекомендації з утримання лабораторних тварин. - К.: Авіценна, 2002. - 156 с.

3. Плохинский Н.А. Биометрия. 2-е изд. - М.: Изд-во МГУ, 1970. - 367 с.

4. Соловьев В.Н., Фирсов А.А., Филов В.А. Фармакокинетика. - М.: Медицина, 1980. - 423 c.

5. Сухарева Г.В. Алкогольная болезнь печени // Гастроэнтерол. - 2003. - T. 5, №3. - С. 26-27.

6. Addolorato G., Ancona C., Capristo E., Gasbarrini G. Metadoxine in the treatment of acute and chronic alcoholism: a review // Int. J. Immunopathol. Pharmacol. - 2003. - Vol. 16. - P. 207-214.

7. Biochemical Nomenclature and Related Documents. 2nd ed. - Portland Press, 1992. - P. 269-271.

8. Calabrese V., Carlino S., Chinnici V. et al. // Revista Italiana di Alcologia. - 1986. - Vol. 5. - P. 44-49. 
9. Ethanol and the liver mechanisms and management / Ed. by D.I.N.Sherman, V.Preedy, R.R.Watson. N.Y.: Taylor \& Francis, 2002. - 689 p.

10. Ink S.L., Henderson L.M., Henderson O. Vitamin B 6 metabolism // Annu. Rev. Nutr. - 1984. - Vol. 4 (1). - P. 455-470.

11. Krahenbuhl S., Brauchli Y., Kummer O. et al. Acute liver failure in two patients with regular alcohol consumption ingesting paracetamol at therapeutic dosage // Digestion. - 2007. - Vol. 75. - P. 232-237.

12. Lieber C.S. Hepatic metabolic and toxic effects of ethanol//Alcohol Clin. Exp. Res. - 1991. - Vol. 15. - P. 573-592.

13. Marco C.A., Kelen G.D. Acute intoxication // Emerg. Clin. North. Am. - 1990. - Vol. 8. - P. 731-748.

14. Vonghia L., Leggio L., Ferrulli A. et al. Acute alcohol intoxication // Eur. J. Intern. Med. - 2008. - Vol. 19 (8). - P. 561-567.

15. Witschi A. The systemic availability of oral glutathione // Eur. J. Clin. Pharmacol. - 1992. - Vol. 43 (6). - P. 667-669.

\section{РЕГУЛЮВАННЯ МЕТАДОКСИНОМ ЕЛІМІНАЦІЇ ЕТАНОЛУ І ЙОГО МЕТАБОЛІТІВ З ОРГАНІЗМУ ЩУРІВ \\ М.Я.Головенко, О.В.Карпова, І.Ю.Борисюк}

Фізико-хімічний інститут ім. О.В.Богатського НАН України

Ключові слова: метадоксин; етанол; ацетальдегід; ацетат; радіологічний аналіз

Розробка патогенетичної терапії гострих отруєнь етанолом представляє безперечний інтерес, так як такі інтоксикації нерідко супроводжуються важким перебігом і високою летальністю. 3 огляду на особливості патологічної дії етанолу, актуальним у лікуванні пацієнтів є застосування препаратів, що володіють комплексним нейро- та гепатопротекторним ефектами. У зв'язку з цим продовжуються пошуки нових лікарських агентів, які мають широкий спектр фармакологічної активності та економічну доступність. Об'єктом уваги дослідників тривалий час залишається хімічна сполука піридоксин-L-2-піролідон-5-карбоксилат (метадоксин). На теперішній час накопичилася велика кількість експериментальних даних, що свідчать про різноманітний фармакологічний профіль дії препарату (антиоксидантний, антистеатозний, протизапальний, антифібротичний, нейротропний). У зв'язку з проблемою, що обговорюється, для нас становить інтерес ще один вид дії метадоксину - дезінтоксикаційний. Тому метою даної роботи стало дослідження впливу метадоксину на швидкість екскреції етанолу та його метаболітів у білих шурів при профілактичному одноразовому введенні препарату. Критерієм оцінки ефективності процесу були обрані показники екскреції ацетальдегіду, ацетату і незміненого етанолу з сечею та калом. Екскреція етанолу легенями і потовими залозами не вивчалась через мізерно малий вклад даних шляхів виведення в процеси елімінації етилового спирту. Встановлено, що метадоксин, введений щурам внутрішньоочеревинно в дозі 200 мг/кг за 30 хв до введення етанолу (перорально в дозі 1 г/кг), прискорює швидкість елімінації етанолу та його метаболітів (ацетальдегіду та ацетату).

\section{РЕГУЛЯЦИЯ МЕТАДОКСИНОМ ЭЛИМИНАЦИИ ЭТАНОЛА И ЕГО МЕТАБОЛИТОВ ИЗ ОРГАНИЗМА КРЫС Н.Я.Головенко, О.В.Карпова, И.Ю.Борисюк}

Физико-химический институт им. А.В.Богатского НАН Украины

Ключевые слова: метадоксин; этанол; ацетальдегид; ацетат; радиологический анализ

Разработка патогенетической терапии острых отравлений этанолом представляет несомненный интерес, так как такие интоксикации нередко сопровождаются тяжелым течением и высокой летальностью. Учитывая особенности патологического действия этанола, актуальным в лечении пациентов является применение препаратов, обладающих комплексным нейро- и гепатопротекторным эффектами. В связи с этим продолжаются поиски новых лекарственных агентов, обладающих широким спектром фармакологической активности и экономической доступностью. Объектом внимания исследователей длительное время остается химическое соединение пиридоксин-L-2-пирролидон-5-карбоксилат (метадоксин). В настоящее время накопилось большое число экспериментальных данных, свидетельствующих о разнообразном фармакологическом профиле действия препарата (антиоксидантное, антистеатозное, противовоспалительное, антифибротическое, нейротропное). В связи с обсуждаемой проблемой для нас представляет интерес еще один вид действия метадоксина - дезинтоксикационный. Поэтому целью данной работы стало исследование влияния метадоксина на скорость экскреции этанола и его метаболитов у белых крыс при профилактическом однократном введении препарата. Критерием оценки эффективности процесса были выбраны показатели экскреции ацетальдегида, ацетата и неизмененного этанола с мочой и калом. Экскреция этанола легкими и потовыми железами не изучалась ввиду ничтожно малого вклада данных путей выведения в процессы элиминации этилового спирта. Установлено, что метадоксин, введенный крысам внутрибрюшинно в дозе 200 мг/кг за 30 мин до введения этанола (перорально в дозе 1 г/кг), ускоряет скорость элиминации этанола и его метаболитов (ацетальдегида и ацетата).

Address for correspondence: 